\title{
Research on China's Financial Macro Prudential Regulation and Coordination of Legal System
}

\author{
Youfang Jin \\ Zhejiang University \\ Hangzhou, China
}

\begin{abstract}
In China's financial industry, the supervision pattern of separate operation and separate supervision is adopted. And the problem is that the regulatory authorities merely pay attention to the duties performing within their respective permissions, which is likely to trigger that they only focus on micro prudential supervision and the risk considerations of the single regulated financial institution, but to neglect the overall macro prudential supervision. And there are absent identification, monitoring, early warning, prevention and emergency response to the systematic risks in the entire financial industry. In order to construct the financial supervision and coordination of legal system, the entire prudential supervision system on macro and micro level and supervision coordination system shall be rethought and arranged, to develop a more perfect legal system in the way of the orientation of institutional regulation and functional supervision, the coordination between the prudential supervisions both micro and macro. It is hoped that this research can contribute to sound operation of China's financial supervision coordination of legal system and provide legal basis for financial supervision coordination.
\end{abstract}

Keywords-Separate Supervision; Regulatory Vacuum; Regulatory Coordination; Systemic Risk

In Article 43 of Law of Commercial Banks of the People's Republic of China, Article 6 of Securities Law of the People's Republic of China and Article 8 of Insurance Law of the People's Republic of China, the supervision modes in China's financial industry are stipulated, and it also makes room for the mixed operation of finance like Mixed Financial Holding Company. As stipulated in the legislation, the vertical separate supervision system of "One Bank and Three Commissions"(1) is applied in the domestic financial industry. Under the system, the financial regulators purely concern about the duties performing within their respective permissions (2), which is likely to trigger that they only focus on micro prudential supervision and the risk considerations of the single regulated financial institution, but to neglect the overall macro prudential

(1) Namely the People's Bank of China, China Banking Regulatory Commission, China Securities Regulatory Commission and China Insurance Regulatory Commission.

(2) China Banking Regulatory Commission responsible for the supervision and management of the national banking financial institutions and the business activities shall perform the duties related to approve and regulate banks, financial asset management companies, trust investment companies and other deposit financial institutions. China Securities Regulatory Commission shall supervise and manage the securities market nationwide based on laws in a centralized and unified way. And China Insurance Regulatory Commission shall regulate the insurance industry by laws. supervision. And there are absences of identification, monitoring, early warning, prevention and emergency response to the systematic risks in the entire financial industry.

Nowadays, efforts are made by the countries in the world to constantly modify the financial supervision model and construct the coordination mechanism of financial supervision, in a bid to make up for the existing defects in the financial supervision system. After the world financial crisis in 2008, the financial supervision coordination mechanism has been increasingly important, which is usually prescribed by law as an effective way to jointly adopted by all countries that are financially developed. [1]In Article 9 of Laws of the People's Bank of China, it is described that "The State Council shall establish a financial supervision and management coordination mechanism, and the specific measures shall be formulated by the State Council”, which has not yet been developed. In spite of some principle clauses like financial information sharing involved in many laws such as Securities Law, there are lacks of specific operational system norms. For the sake of preventing the financial systemic risk supervision, it is urgent to enact the financial supervision coordination legislation, improve the macro prudential supervision and coordination of legal system, and strengthen the identification ability of the national financial supervision and management departments on the financial systematic risk.

\section{LACK OF REGULATORY COORDINATION ON IDENTIFYING THE SYSTEMATIC FINANCIAL RISK}

In the past, there is a basic law value orientation in the financial regulatory system and its legal system in various countries, including Basel Accord as the international regulatory standards for the financial sector, which is to only focus on the micro prudential supervision and to neglect the more important systematic risk on the macro level and the importance of protecting the rights and interests of financial consumers. After the financial crisis, people are conscious of that the financial risks caused by any financing institution may quickly spread throughout the global financial system in the context of cross-border business of the financial sector and Internet, and the ignorance of macro prudential supervision will make it unlikely to prevent the financial systemic vulnerability. At the same time, the financial consumer is an important part for the stable operation of financial system, and the financial industry can flourish steadily and sustainably until the financial consumer protection is taken seriously as systemic risk prevention.[2]And for realizing the target of financial stability 
and consumer protection for both sides, financial supervision and coordination, which is a basic system determined by the legal institutions, is perceived as the fundamental means.

In China, the existing laws like Law of the People's Bank of China, Securities Law and Trust Law were enact before the global financial crisis broke out in 2008, but the world at that time had never woken up to the relationship among financial macro prudential supervision, micro prudential supervision, financial stability and security as well as consumer protection and its importance. It is taken into the consideration when designing the system and the regulatory coordination system design based on these issues is not pondered. Moreover, the separated supervision adopted by the financial institutions in the long term as well as the legislation keynote of prudential supervision on the micro level has been entrenched. The institution-based supervision by the current banking, securities and insurance industries of China is to prevent the occurrence of financial institutional risks and financial enterprise bankruptcy more precisely. Confronted with the occurred risks, the financial institutions tend to adopt the methods in an oversimplified and crude way like takeover for reforming and even declaration of bankruptcy. In short, the severe shortage of legal system arrangements to coordinate prudential supervision both macro and micro as well as great lacks of legal provisions on identification, monitoring, early warning, prevention and emergency response to the systematic risks happen in the existing legal system of China.

\section{Suggestions on Perfecting Macro Prudential REGULATION AND COORDINATION OF LEGAL SYSTEM}

Macro prudential supervision refers to the financial supervision implemented by the macro financial management authority from the perspective of the whole financial system rather than the single institution, in a bid to stabilize finance. And the micro prudential supervision focuses on the regulation on the individual financing institution. Micro prudential supervision theory argues that the stability and safety of the single financial institution will bring that to the whole financial system, which proved to be wrong by the global financial crisis starting in the United States in 2008. At present, the financial institutions in all China's financial industry are interpenetrative and there are many shadow banks. Non-bank financial institutions and non-financial institutions serve as the credit intermediaries and the legal institutional regulation and separated supervision come under question. And the development of Internet finance obfuscates the boundaries between banks, securities, insurance, finance and non-finance. All of these factors have triggered the further interlaced individual risk and systemic risk, and it is likely to infect the risks across the industries, borders, organizations and markets. The entire prudential supervision system on macro and micro level and supervision coordination system shall be rethought and arranged, to develop a more perfect legal system in the way of the orientation of institutional regulation and functional supervision, the coordination between the prudential supervisions both micro and macro.[3]

\section{A. Amend Macro and Micro Prudential Regulation and Coordination of Legal System}

China's existing financial laws and regulations attach importance to the micro prudential supervision and the rights and responsibilities required for macro prudential regulation shall be defined in the laws. For example, "To prevent and dissolve financial risks and maintain financial stability" stipulated in Law of the People's Bank of China merely focuses on the stable monetary policy and the micro prudential supervision responsibilities of the People's Bank on the banking sectors. It is aimed at the cross coordination relationship with the banking industry, without involved in the institutions like securities industry and insurance industry as well as the monitoring, inspection, risk identification and emergency response to the financial activities of the nonlicensed institutions. In Law of Commercial Banks, Securities Law and Insurance Law, it is prescribed that the micro subjective regulation and trading behavior norms shall be concerned, followed by the consumer protection. Accordingly, it is necessary to establish the special macro prudential supervision department and the macro prudential regulation authority as Britain do and define the responsibilities of departments. And it shall also pay attention to the identification and monitoring of the risks of individual financial entity and systemic risk, restricting the transfer of individual risk and systematic risk between individual institutions. The macro prudential regulator shall be adequately empowered to collect and share the data information of the system in one country, and impose the certain pressure on the financial institutions with unstable business based on the analysis on the understood and grasped information, so as to guarantee the effective supervision.[4]

\section{B. Expand the Supervision Scope of "One Bank and}

\section{Three Commissions"}

In China, there are too narrow scopes for financial transactions regulation determined by the current "One Bank and Three Commissions". Taking the case for payment field, the system of the People's Bank is lack of regulations on money transfer service provider (akin to Alipay business of China) in the early days and it was not started passively until 2012. In the field of securities, the financing behaviors in the scope of securities are not regulated, with the exception of small issue exemption.[5] China has adopted different regulation modes for financing behavior and eliminated the masses of investment tools conforming to the securities features from the scope of securities, compared to America which is to incorporate the financing behavior into the adjustment of Securities Law by extending the concept of "securities"(3).[6] Professor Wu Zhipan had ever talked that the application scope and adjustment object in Securities Law had constrained the variety of market securities and market division, resulting in small and medium-sized enterprises' failure in financing by the securities market.[7]The substantial securities financing of non-stock and corporate bond cannot be included

(3) As prescribed by Securities Law of China, the securities consist of stock and corporate bonds, not including the other financial equities credentials and property equities credentials. So far, the State Council has not identified other securities varieties yet. 
in the adjustment of Securities Law, implying CSRC's failure in conducting the supervision because of lacking statutory competence. However, the same problem can be identified as the scope of securities in the United States and regulated by the Securities Act of the country. For the sake of enhancing the effective macro prudential supervision, China is expected to expand the scope of prudential supervision and incorporate the large-scale financing and lending business as well as shadow banking system of capital transfer into the regulation, urging the financial institutions and non-bank financial institutions to restrict the behavior of their own and eliminating the risk of illegal transfer.

\section{Build the Statutory Memorandum of Understanding System}

According to Australian financial supervision experience, Memorandum of Understanding signed by both parties is the important path to realize supervision, in which both sides make arrangements for the problems like division of supervision, regulatory vacuum, regulation conflict, mutual information sharing, negotiation and communication, mutual supervision and procedure in the framework of legal system. The Memorandum of Understanding with statutory force shall be signed and implemented by all parties, and it is the best comparative document to assess whether the regulatory authorities perform responsibilities or not. Among the people's Bank of China, three financial regulators, the Ministry of Finance, the National Development and Reform Commission, the local government and other regulators, Memorandum of Understanding system, which is signed by both parties instead of various parties and to prescribe the contents like regulation, duties, obligations, execution, supervision and accountability involved in the regulatory domain and derivative field of both sides, shall be adopted. And the coordination and cooperation contents that are not detailed in the law can be further supplemented in Memorandum of Understanding. At the same time, the contents written in the Memorandum shall be disclosed timely, to supervise the behavior of the regulators.

\section{Establish the Coordination and Interaction System between Financial Institutions and Self-regulatory Organizations in the Financial Industry}

"In terms of the institutional arrangement of financial supervision, the "disorder" of market and the "autocracy" of the government shall be balanced, and the effective regulation shall play a role in restricting the market, thus finding the best between two sides after constant trial \& error. Nowadays, China's financial supervision has been challenged as never before, including the governance and non-governance problems between macro supervision and micro supervision, institutional supervision and functional regulation, comprehensive supervision and target regulation, Internet finance, informal finance and shadow banking system, how to handle the relationship between the market and the government as well as the confusion existing in the governance in accordance with law. Under this circumstance, it is better to carry out self-discipline supervision in the industry with the help of industrial organizations. ${ }^{(4)}$ For China, the coordination and interaction system for financial supervision institutions and self-discipline organization in the industry shall be prescribed legislatively, making the best of self-regulatory organizations function. In the formal financial legal system of China, the established relationship model between financial industry organizations and government regulatory authorities is basically consistent, which is that the activities of selfdiscipline organizations in the financial sector are under the guidance and supervision of the government financial regulation departments. (5) At present, the "formal finances" with complicated principal parts, disparate levels and great differences, such as non-governmental finance and Internet finance which are different from banks, are prevailing in China. Integrating industry self-regulation with the government supervision helps to improve the governance level of private financial market. Serving as the industry expert, the industrial organizations have the most understanding of characteristics, risk points and bottom line of the industry, the essential conditions for standardized operation of industry enterprises, industry regulation, industry enterprise risk source, development and trend as well as the basic laws of prediction, monitoring, early warning, prevention and disposal. And selfregulation in possession of flexibility and timeliness cannot merely reduce the cost of supervision but also takes the professional advantages. Therefore, it is expected to design and define the legal status of the financial industry association from the perspective of legal system as well as the coordination and interaction with the government financial regulatory authorities.

\section{CONCLUSIONS}

The separate supervision system of "One Bank and Three Commissions” is applied in China's financial industry. Under the circumstance of mixed operation of the financial industry and the financial holding company prevailing and Internet finance (including payment, P2P and crowd funding ), the third-party financial and shadow banking abounding, it is confronted with the issues like regulatory vacuum, regulatory overlap and regulatory conflicts. In the separate supervision system, the financial supervision and coordination shall be strengthened no matter which supervision mode is adopted. And the effective coordination of financial supervision shall be conducted under the guarantee of legal system. Therefore, the country shall accelerate the legislation of financial supervision and coordination and set up the legal system, realizing the harmony and coherence as stipulated by the legal system. The macro prudential supervision and coordination system makes great differences on preventing the financial systemic risk. So the rights and responsibilities required for macro prudential regulation shall be defined in the laws, the financial supervision scope of "One Bank and Three Commissions” shall be expanded, the statutory Memorandum of Understanding

(4) In April, National Internet Finance Association of China which was established under the guidance of the People's Bank of China has been approved by the State Council.

(5) As stipulated in Article 31 of Banking Supervisory and Administrative Law, the banking supervision institution of the State Council shall guide and supervise the activities of the banking self-discipline organizations. 
system shall be set up and the system for the coordination and interaction of financial institutions and self-discipline organization in financial sector shall be established. We are hoping for the further improved legal system of China's financial supervision and coordination and the healthy development of the financial sector.

\section{REFERENCES}

[1] Kelin. Bo, "Why are Financial Supervision and Coordination Mechanism Absent for One Decade [N]?” International Financial News, vol. A1,2014, pp:6.

[2] R.Z. Li, Y. Zhou, "Financial Consumer Protection and the Reform of International Financial Supervision Legal System,” Journal of Wuhan
University: Philosophy and Social Sciences Edition, vol.6, 2013, pp:16. (In Chinese)

[3] Z.X. Wang, "Reorientation of Financial Supervision," China Finance, 2014, pp:13-16. (In Chinese)

[4] X.Q.Zeng,"Research on Financial Globalization and Financial Supervision Legislation,” Beijing: Peking University Press, 2005, pp:175-176. (In Chinese)

[5] B.Peng, China Securities Law (Second Edition), Beijing: Higher Education Press, 2007. (In Chinese)

[6] Y.X. Li, J.H., "Analysis on Non-specific Object Standard in Illegal Fundraising---A New Interpretation from the Perspective of Private Securities," Journal of Zhejiang University (Humanistic and Social Sciences Edition), vol.5, 2011, pp:127-137. (In Chinese)

[7] Z.P. Wu, "Reflection and Prospect of the Applicable Scope of Securities Law," Study in Law and Business, vol.2, 2003, pp:13-22. (In Chinese) 